\title{
Texts and Abbreviations
}

In quoting from, and citing, Greek and Latin texts I follow the latest $O C T$ editions for most authors. Where I deviate from N.G. Wilson's edition of Aristophanes (2007), this is made explicit. I use R. Kassel and C. Austin, Poetae Comici Graeci (1983 - ) for comic fragments; B. Snell, R. Kannicht, and S. Radt, Tragicorum Graecorum Fragmenta (1986 - ) for tragic fragments; M.L. West, Iambi et Elegi Graeci (1989-1992), D.L. Page, Poetae Melici Graeci (1962), and E. Lobe and D.L. Page, Poetarum Lesbiorum Fragmenta (1955) for the respective categories of lyric poetry. The translations are from Loeb (thus J. Henderson for Aristophanes), or of my own when necessary, unless otherwise stated in the footnotes. The names of ancient authors and the titles of their works are abbreviated according to the $O C D$ (thus Aesch. instead of A. for Aeschylus, or Eccl. instead of Ec. for Ecclesiazusae), unless they are not included there and except for the Greek Anthology, in which cases I follow the abbreviations of $L S J$ (thus AP instead of Anth. Pal., or Hippon. for Hipponax). Journals are abbreviated according to L'Année philologique (thus TAPhA instead of TAPA, or AJPh instead of AJP). 
